\title{
Heterogeny In Analyses of The Greek God Hermes: A Systematic Review
}

\author{
Trevor C Hunt BA* \\ College of Health Professions, The University of Phoenix, Phoenix, AZ, USA
}

*Corresponding author: Trevor C Hunt BA, College of Health Professions, 4035 S Riverpoint Pkwy, Phoenix, AZ, USA

\begin{abstract}
Hermes was the ancient Greek god of trade, wealth, luck, fertility, animal husbandry, sleep, language, thieves, and travel. One of the cleverest and most mischievous of the Olympian gods, he was the patron of shepherds, invented the lyre, and was, above all, the herald and messenger of Mt. Olympus so that he came to symbolize the crossing of boundaries in his role as a guide between the two realms of gods and humanity. To the Romans, the god was known as Mercury. Herein, we present a review of the literature expounding upon significant heterogeneity in the classical understanding and interpretation of this figure within urology.
\end{abstract}

Keywords: Urology; Hermes; Greek; Mythology; Review

\section{Main Text}

The Slayer of Argos; Keeper of the Flocks; Messenger of the Gods: all of these are epithets for the glorious Greek god Hermes that appear in the urologic literature. Indeed, Hermes is quite the multifaceted character in the Greek mythological tradition. As with most Olympians, he occupies a wide range of positions among the Immortals and appears in a vast amount of mythic tales. Naturally, with such a broad range of material composed over such an expansive time period, the characteristics that define Hermes are not always set in stone. Akin to a headless marble sculpture, the main components of Hermes' character are universal throughout Greek mythology, yet the more specific details were often decided by each individual author. The majority of works present a rather one dimensional Hermes, casting him as either a brave and glorious messenger or a bold and wheedling trickster; however, the Homeric Hymn to Hermes appropriately fuses these two contrary characterizations and presents a holistic view of Hermes that is both accurate and functional.

Hermes takes on an almost entirely positive role in Hesiod's Theogony as well as in the Homeric Hymn to Apollo and the Homeric Hymn to Demeter. While only mentioned twice in the extremely broad work that is the Theogony, Hermes is given some of his most crucial traits. His power over animals and ability to make them mate and produce offspring is referenced early on in a passage speaking primarily of Hecate, who shares the same power [1]. Later in the work, Hesiod uses the phrase "glorious Hermes" and refers to him as "the Immortals' herald" when describing his lineage from Zeus and the Atlantid Maia, who is the daughter of the Titan Atlas[1]. Although only two lines, Hesiod's words were not chosen lightly, as "glorious Hermes" is a meaningful and commonly used epithet throughout Greek mythology. For the most part, Hermes is a very likeable and positive character. He embodies many of the characteristics of the ideal Greek, albeit not to the same level as Apollo. As the direct descendant of Zeus, he is expected to be wise, fair, and morally inclined, and this is generally the case, admittedly with a handful of exceptions cropping up in his early youth. Furthermore, Hermes' blood relation to the Titans probably played a part in the incredible strength that he is born with, which impresses even his fellow gods [2]. As messenger of the gods, Hermes must constantly represent the will of Zeus and his fellow Olympians, so it is only natural that his leadership skills are superior to that of most other Immortals. This aptitude for 
leadership is displayed indirectly when Apollo divulges his desire to both prophesy the will of Zeus and play the lyre,[3] which is an instrument that Hermes himself invented. Prophesy in Greek myth is a form of divine leadership bestowed as a riddle upon mortal worshipers, and the author uses the association of prophesy with the lyre as a way to reference the elevated leadership skills that Hermes possesses. Furthermore, a slightly more literal example is the march of Apollo and his Cretan followers to his oracle at Pytho. During this march, Apollo plays his beloved lyre while the Cretans, following behind, beat time and sing joyously [3]. In contrast to these obscure references to Hermes' intrinsic qualities, more direct characterizations are present in the Hymn to Demeter, in which Demeter casts a curse on the Earth's agriculture because her beloved daughter Persephone is taken to the Underworld by the god Hades. As herald of the Immortals, Hermes is sent to Erebos to reason with Hades and ultimately bring Persephone back to her mother, 4 a task in which he is successful. Specifically, Zeus uses the phrase "wheedle Hades with soft words" when describing Hermes' task [4]. In doing so, Zeus alludes to Hermes' cunning mind and persuasive diction which are crucial to his success in the rescue of Persephone. Indeed, the myth paints a rather heroic picture of Hermes as the savior of Persephone. By venturing bravely into the depths of Hades in search of a damsel in distress, Hermes embodies the heroism associated with modern day firemen, who boldly enter burning buildings to rescue those who are trapped and unable to save themselves. Further cementing his role as a brave and glorious savior is the epithet that he is referred to by, Slayer of Argos [4]. Argos was a monstrous herdsman with eyes all over his body that Hera requisitioned to guard Io during the period in which Zeus lusted for her. At the bidding of Zeus, Hermes loyally sought out and slayed Argos, which was not an easy task as Argos was very similar to Hermes in that he was both swift and cunning. In completing his duties, Hermes earned the prestigious title Slayer of Argos. This heroism, combined with the wisdom, loyalty, and leadership that Hermes possesses is often demonstrated by Greek authors who prefer to shed a positive light on Hermes' character.

On the contrary, a more mischievous, dishonest undertone is present in Hermes' character in works such as Aeschylus' Prometheus Bound and Hesiod's Works and Days. At its most basic level, this morally defunct characterization of Hermes is visible in Hesiod's didactic poem. The Works and Days functions as a moral code of sorts for Greek citizens. This serves to heighten the contrast between the good morals recommended by Hesiod and the deficit thereof in Hermes' character, which draws the reader's attention immediately to him. In the section dealing with life's hardships, Hesiod says that Zeus, in retribution for Prometheus' gift of fire to man, commissions the gods to create a woman named Pandora [5]. Into this woman, at Zeus' request, Hermes puts "lies and wheedling words and a cheating heart",[5] which of course came from inside of him. Hermes' foul play does not stop here, however, as Zeus also asks him to deliver the troublesome Pandora to the human whom Prometheus had given fire to, a task which Hermes gladly completes. Pandora is given to Epimetheus disguised as a gift, leading to the opening of Pandora's Box and the scattering of miseries and displeasures into the mortal world.5 What is striking about this tale is not necessarily its subject matter, but the new and dishonorable traits associated with Hermes. While still the loyal and wise messenger of Zeus, he is now additionally portrayed as being skilled in the ways of trickery. Specifically, Zeus references his "wheedling words"; [5] no longer is Hermes merely skilled in debate and persuasion, he is now seen as achieving these ends through deceptive means. It is ironic that this evolution in Hesiod's portrayal of Hermes comes in a poem that is centrally concerned with teaching good values. Additional dark elements of Hermes' personality make themselves known in the Prometheus Bound. The Titan Prometheus has been bound by Zeus for the crime of, contradictory to Hesiod's account, giving fire to the race of mortal men. Late in the play, Hermes enters, acting as the loyal mouthpiece of Zeus, who wants Prometheus to divulge a piece of information that is crucial to the continuation of Zeus' reign over the Immortals [6]. In a manner that is rarely, if ever, seen in his character Hermes speaks quite authoritatively to Prometheus, criticizing and belittling him at every opportunity. Right from the start, Hermes has an attitude similar to that of a playground bully, picking on Prometheus and calling him names [6]. This is a striking contrast to the glorious, heroic Hermes portrayed in other works such as the Hymn to Demeter. In his defense, Hermes does attempt to help Prometheus' situation, trying to get him to see reason and submit to the will of Zeus, as he can gain nothing by opposing it.6 However, Hermes still resorts to childish impulsiveness; when Prometheus mocks Hermes' position, calling him a mere errand boy, Hermes quickly retorts with a sarcastic verbal blow[6]. Such bickering is unseemly among divine beings, especially one as revered as Hermes. Despite both his bullying tactics and his genuine, earnest attempts to help Prometheus see reason which are approved of by the Leader character, who confirms Hermes' wisdom,[6] Hermes makes no progress with Prometheus and resorts to a blunt show of power in which he describes Zeus' impending wrath.6 This is a drastic contrast to the mainstream Hermes who is generally able to accomplish his ends, whether they are noble or mischievous, via wisely chosen words and his compelling persuasiveness. While both the Works and Days and the Prometheus Bound expose Hermes' dishonest side, Aeschylus' poem is truly unique in that it portrays a menacing Hermes does not present in other areas of the Greek tradition.

Whereas other works tend to show a rather limited view of Hermes' personality, the Homeric Hymn to Hermes presents the big picture, drawing upon all other sources and presenting a 
complete, unabridged representation of the glorious Immortal. In 3-D cinematography, two offset images in two contrasting colors are projected onto the screen. In Greek mythology, Hermes is often portrayed as such; the same image of him appears in many different works, but the colors vary between two primary shades. Only when one looks through a set of 3-D glasses does the true image materialize. The Homeric Hymn to Hermes is the mythological equivalent of a pair of these glasses, as it takes from the two differing characterizations of Hermes often seen in the Greek tradition and combines them in a way that paints a splendid picture of who he really is. The myth largely avoids discussing Hermes' position as Zeus' messenger, which is already widely known among the tradition, and instead focuses on his moral development during childhood and his ascension to a position among the Olympians. On the day of his birth, the author immediately speaks of Hermes as being "wily and wheedling",[2] the latter of which is a term found in many other works when describing Hermes' vexatious side. Miraculously, on his first day of existence, Hermes demonstrates his cunning mind and insistent curiosity by killing a tortoise and fashioning a wonderful new instrument out of it, the lyre [2]. Not satisfied with just this accomplishment, he contemplates "devices of deepest deception" and then sets out to the mountains of Pieria to steal 50 cows from his brother Apollo [2]. While only a mere 70 lines into the work, it is already clear that the author is fully blending Hermes' mischievous traits with his adventurous ones. Gravity is added to the matter by the fact that all of this is occurring on Hermes' first day of life, implying that both his morally good and bad components were present from birth, before Hermes ascended to power at Olympus. In contrast to mortals, whose morals are most aligned at birth and tend to decay as they obtain more and more power, Hermes was born with a jumble of both morally good and morally bad characteristics, the latter of which only began to be curtailed when he ascended to power as Zeus' herald. In stealing Apollo's cows, Hermes again demonstrates his cunning and deception by reversing their hooves so that their tracks point the opposite direction[2]. For himself, he wisely invents wicker sandals so as to disguise his footprints as well.2 He then demonstrates his surprising strength when he wrangles two of the cattle and kills them, 2 a feat which later impresses even Apollo, who is the epitome of the Greek male [2]. Apollo is also impressed by the hoof trick and the wicker sandals, which serves to justify Hermes' clever deception in addition to his strength and heroism. This theme, that both the good and bad aspects of Hermes' personality are just and should be praised, permeates throughout the work and is a crucial element in the development of Hermes' character in the mythic tradition. His deception comes to a climax when Hermes uses "ruses and tricks and flattering words" to deceive Apollo and then proceeds to blatantly lie to his father Zeus' face about his theft of the cows [2]. Zeus responds with laughter at his child's wisdom in evil ways, but swiftly asserts his authority by instructing Hermes to show Apollo where he has hid the cattle [2]. This interaction carries heavy implications as it again justifies both contrasting sides of Hermes' personality, this time from the highest moral judge in the land, Zeus. Furthermore, it also serves as the first instance in Hermes' life in which he, albeit unknowingly, serves as Zeus' loyal messenger by bending to his will. In addition, it presents Hermes' intense likability as a god in Greek mythology, demonstrating that he can lie to even the chief god and still garner his approval. Additionally, Hermes is later able to earn Apollo as a close friend when he gives him the lyre that he crafted in order to resolve an argument [2]. So great is Apollo's reverence for Hermes and his wonderful lyre that 20 lines are dedicated solely to his awe [2]. This scene again reinforces Hermes' astounding likability among the gods while also demonstrating his selflessness and his compelling ability to settle nearly any quarrel using merely words. In a show of honesty that boldly balances out his earlier deeds, Hermes vows never to steal from Apollo,[2] which contrasts with his earlier intentions to break into and rob Apollo's house. At this point, although only two days old, it is possible to see a deep maturation that has occurred in Hermes' moral code. While still retaining an aptitude for deception and trickery, lines have now been drawn in his conscience as to what situations allow for the exercising of these methods. As both messenger of Zeus and sole courier to Hades, [2] Hermes occupies positions that require him to utilize every single drop of wisdom, ingenuity, and occasionally, trickery that he possesses. While quietly acknowledging the positive characteristics generally associated with Hermes, the Homeric Hymn to Hermes serves to justify the manner in which these noble traits coexist with his less morally-sound attributes, which ultimately allows for the creation of a character that is much more versatile than versions seen in the majority of other Greek myths[7].

Despite his appearance in an abundance of mythic material, the truly complete portrayal of Hermes' character is seen almost exclusively in the Homeric Hymn to Hermes. While other works such as the Hymn to Demeter, Hymn to Apollo, Prometheus Bound, Works and Days, and the Theogony can present a two dimensional view of Hermes, the Hymn to Hermes smelts all other views together and delivers a living, breathing manifestation of Hermes that is impeccably complete. Given the nature of Greek myth, it is possible to paint a big picture of a god or goddess by looking at a variety of primary sources, but the individual brush strokes will always vary from work to work. Still, when it comes to Hermes, the Homeric Hymn to Hermes is a true Mona Lisa akin to the success of the robotic-assisted laparoscopic prostatectomy [8]. 


\section{References}

1. Hesiod. "Theogony." In: Harris and Platzner pp.88-105.

2. “Homeric Hymn to Hermes." In: Harris and Platzner pp.209-223.

3. “Homeric Hymn to Apollo." In: Harris and Platzner pp.134-142.

4. “Homeric Hymn to Demeter." In: Harris and Platzner pp.156-167.
5. Hesiod. "Works and Days." In: Harris and Platzner pp.128-133.

6. Aeschylus (2013) "Prometheus Bound."

7. Harris, Stephen L, Gloria Platzner, eds (2012) Classical Mythology: Images \& Insights. $6^{\text {th }}$ ed. New York: Mcgraw-Hill.

8. Schuessler WW, Schulam PG, Clayman RV, Kavoussi LR (1997) Laparoscopic radical prostatectomy: initial short-term experience. Urology. 50(6): 854-857. (c)

This work is licensed under Creative

Commons Attribution 4.0 License

To Submit Your Article Click Here: Submit Article

DOI: 10.32474/RRHOAJ.2020.05.000223

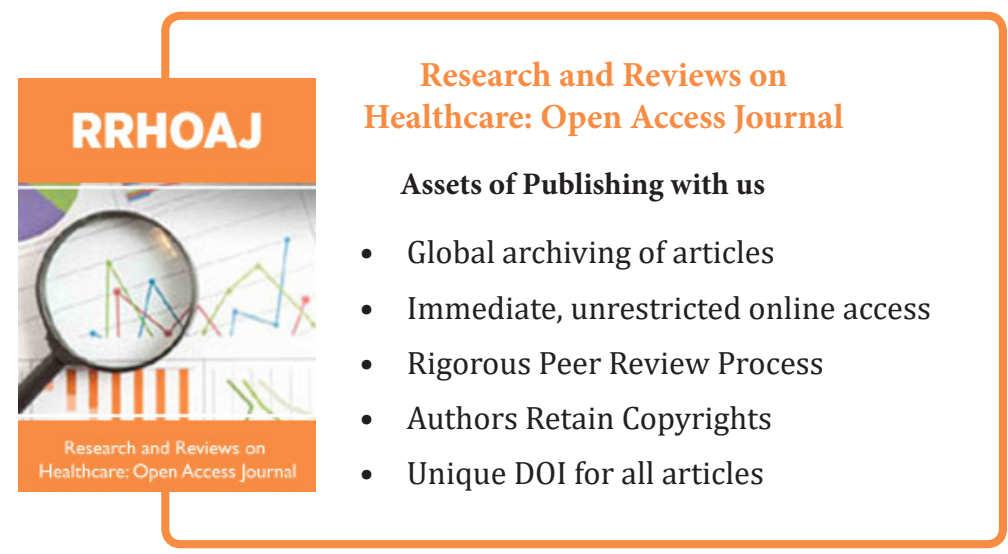

